\title{
Analisis Bauran Pemasaran Produk Properti Pada PT. HTI Mandiri Palembang
}

\author{
Oktariansyah \\ Fakultas Ekonomi Universitas PGRI Palembang, \\ email: abanghafizbro06@gmail.com
}

\begin{abstract}
ABSTRAK
Tujuan penelitian ini adalah untuk mengetahui bagaimana bauran pemasaran produk rumah yang diterapkan pada PT. HTI Mandiri Palembang dan untuk mengetahui bagaimana analisis SWOT pada PT. HTI Mandiri Palembang. Variabel dalam penelitian ini adalah bauran pemasaran yang terdiri dari produk, harga, tempat dan promosi pada PT. HTI Mandiri Palembang. Data yang digunakan dalam penelitian ini adalah data primer yaitu data asli yang dikumpulkan oleh penulis untuk menjawab masalah penelitiannya. Metode pengumpulan data yang digunakan yaitu dengan teknik observasi, wawancara dan dokumentasi. Metode penulisan yang digunakan yaitu dengan metode analisis kualitatif dan dibantu dengan analisis SWOT. Kesimpulan dari skripsi ini adalah strategi bauran pemasaran yang diimplementasikan oleh PT. HTI Mandiri Palembang sudah baik hanya bauran promosi saja yang dalam pelaksanaannya tidak begitu maksimal.
\end{abstract}

Kata Kunci : Produk, Harga, Tempat, Promosi dan Analisis SWOT

\section{A. Latar Belakang}

Dewasa ini perkembangan penduduk di Indonesia sangatlah signifikan, hal ini berdampak pada peningkatan jumlah kebutuhan pokok manusia baik sandang, pangan dan papan. Pemenuhan kebutuhan papan atau perumahan merupakan aspek yang penting mengingat fungsi rumah yang sangat vital sebagai tempat tinggal. Keadaan ini tentu saja akan mempengaruhi permintaan akan produk rumah.

Dalam hal ini pemerintah berupaya untuk menambah jumlah dan membangun perumahan serta membuka kesempatan yang luas bagi Warga Negara Indonesia dimana perusahaan-perusahaan swasta ikut berperan dalam penyediaan produk perumahan dan pemukiman. Peluang tersebut dimanfaatkan dengan baik oleh para pengembang yang fokus terhadap produk berupa perumahan. Persaingan di bisnis ini sangat kompleks sehingga diperlukan strategi yang matang dalam melakukan pemasaran produk perumahan ini.

Pemasaran sebagai suatu sistem dari kegiatan-kegiatan yang saling berhubungan sehingga konsumen mendapatkan kebutuhan dan keinginan serta kepuasan. Gitosudarmo (2008:1) mendefinisikan pemasaran sebagai suatu kegiatan yang mengusahakan agar produk yang dipasarkannya itu dapat diterima dan disenangi oleh pasar.

Semakin bertambahnya

perusahaan di Sumatera Selatan membuat tingkat persaingan semakin kuat. Perusahaan di Sumatera Selatan harus berani menghadapi persaingan dengan meningkatkan kemampuan serta berinovasi demi perkembangan dan kemajuan perusahaan. Persaingan secara khusus meningkat di Sumatera Selatan dengan kondisi permintaan konsumen yang kuat, pemasok yang kuat dan potensi perusahaan yang tinggi pada industri yang saling berhubungan.

Persaingan yang kompetitif akan meningkatkan efisiensi dengan berkembangnya perusahaan, pasar dan distribusi produk dan jasa di Sumatera Selatan. Kekuatan persaingan yang tajam antar perusahaan yang satu dengan yang lainnya mengakibatkan perusahaan 
berlomba-lomba untuk mendapatkan konsumen apalagi daerah Sumatera Selatan merupakan pangsa pasar yang strategis karena berdekatan dengan Pulau Jawa, Singapura dan Malaysia.

PT. HTI Mandiri Palembang harus mengetahui dimana lokasi yang strategis. Lokasi strategis merupakan lokasi yang mudah dijangkau konsumen serta memudahkan perusahaan dalam memasarkan produknya. Salah satu lokasi strategis di Sumatera Selatan adalah Palembang. Banyaknya jumlah penduduk serta luasnya pasar merupakan peluang yang menguntungkan bagi perusahaan di
Palembang seperti yang dilakukan oleh PT. HTI Mandiri Palembang (perusahaan ini menjalankan usahausaha di bidang property).

PT. HTI Mandiri Palembang memiliki permasalahan yaitu target pemasaran yang sering tidak tercapai sesuai dengan keinginan. Perusahaan menginginkan produk terjual dalam waktu yang singkat. Perusahaan menawarkan rumah yang modern untuk memenuhi permintaan konsumen yang semakin meningkat. PT. HTI Mandiri Palembang menawarkan rumah dengan berbagai tipe dan harga. Tipe rumah, daftar harga dan luas tanah dapat dilihat pada tabel 1 berikut ini:

\section{Tabel 1}

\section{Harga, Luas Tanah dan Type Rumah PT. HTI Mandiri Palembang}

\begin{tabular}{|c|c|c|c|}
\hline Blok & Type & Luas Tanah $\mathrm{m}^{2}$ & Harga Jual (Rp) \\
\hline A & 88 & 241,0 & $1.110 .000 .000,-$ \\
\hline B & 76 & 198,0 & $739.000 .000,-$ \\
\hline C & 96 & 198,0 & $760.000 .000,-$ \\
\hline D & 76 & 198,0 & $739.000 .000,-$ \\
\hline E & 110 & 144,0 & $1.189 .000 .000,-$ \\
\hline F & 76 & 144,0 & $685.000 .000,-$ \\
\hline G & 55 & 108,0 & $499.000 .000,-$ \\
\hline H & 55 & 160,0 & $615.000 .000,-$ \\
\hline I & 55 & 145,0 & $535.000 .000,-$ \\
\hline J & 76 & 138,0 & $595.000 .000,-$ \\
\hline K & 55 & 148,0 & $541.000 .000,-$ \\
\hline L & 76 & 187,0 & $715.000 .000,-$ \\
\hline M & 76 & 170,0 & $698.000 .000,-$ \\
\hline N & 76 & 208,8 & $753.000 .000,-$ \\
\hline O & 76 & 246,3 & $825.000 .000,-$ \\
\hline P & 76 & 268,7 & $847.000 .000,-$ \\
\hline
\end{tabular}

Sumber : PT. HTI Mandiri Palembang Tahun 2017

Rumah dibuat dengan desain yang sama setiap tipenya dengan warna rumah yang sama namun hal ini terkadang membuat konsumen menjadi kurang puas karena konsumen menginginkan bentuk dan 
warna rumah yang variatif. Perusahaan memberi kemudahan kepada konsumen untuk merubah bentuk atau konsep rumah sesuai keinginannya tetapi ada biaya tambahan yang dibebankan kepada konsumen. Sebagian besar konsumen menginginkan konsep dan bentuk yang berbeda yang sesuai dengan keinginannya akan tetapi konsumen keberatan untuk membayar biaya tambahan yang dibebankan kepada mereka. Perusahaan melakukan kebijakan yaitu biaya tambahan yang dibebankan kepada konsumen dikarenakan membutuhkan bahan baku yang lebih banyak untuk digunakan.

Untuk memenuhi permintaan rumah di Kota Palembang, perusahaan juga melakukan penjualan rumah secara kredit dan tunai. Penentuan harga jual rumah secara kredit relatif lebih tinggi dibanding dengan harga rumah pesaingnya. Namun perusahaan menyiasati dengan memudahkan konsumen membeli secara kredit dengan uang muka yang kecil (down payment) karena kesalahan dalam penetapan harga sangat berpengaruh terhadap minat konsumen untuk membeli rumah tersebut.

Perusahaan juga melakukan penjualan rumah secara tunai dengan harga terjangkau. Harga rumah yang dibeli tunai jelas relatif lebih murah dibandingkan harga rumah yang dibeli secara kredit. Konsumen ingin mendapatkan diskon jika membeli rumah dan secara tunai namun perusahaan tidak dapat memberikan diskon karena harga rumah sudah sesuai dengan biaya pembuatannya.

Jika perusahaan kurang memperhatikan harga pasar rumah yang akan dijual, hal ini akan berdampak buruk karena dapat membuat citra negatif perusahaan dimata konsumen, konsumen bisa saja beralih membeli rumah kepada perusahaan lain. PT. HTI Mandiri Palembang juga memperhatikan lokasi pembangunan rumah yang strategis karena lokasi juga akan mempengaruhi daya tarik konsumen untuk membeli rumah yang ditawarkan. Namun perusahaan cukup sulit untuk mendapatkan lokasi dan luas tanah yang diinginkan karena modal perusahaan cukup terbatas untuk membeli tanah yang luas di lokasi yang strategis serta kuatnya daya saing perusahaan lain yang memiliki modal yang lebih besar. Lokasi yang kurang strategis akan mengakibatkan konsumen ragu dalam membeli rumah apalagi jika perusahaan kurang memperhatikan infrastruktur jalan dan keamanan yang mendukung di lokasi tersebut. Tapi perusahaan tetap yakin atas kebutuhan konsumen untuk membeli rumah akan tetap tinggi sejalan dengan pertumbuhan penduduk yang semakin meningkat.

PT. HTI Mandiri Palembang menyediakan tempat pembelian rumah untuk memudahkan konsumen membeli rumah. Tempat pembelian rumah berada dilokasi yang dibangun sebagai kantor pemasaran. Perusahaan menyerahkan wewenang penjualan kepada karyawan bagian marketing. PT. HTI Mandiri Palembang melakukan promosi penjualan. Hal ini karena kegiatan pemasaran sangat kompleks dan saling berkaitan yang satu dengan yang lainnya seperti promosi dan penjualan. Perusahaan berusaha mengelola promosi dengan baik untuk mencapai tujuan perusahaan yaitu laba. Promosi berfungsi untuk meningkatkan volume penjualan juga berfungsi sebagai strategi untuk menjangkau pembeli untuk melakukan pertukaran. 
$\begin{array}{ccc}\text { Promosi } & \text { yang dilakukan } \\ \text { perusahaan } & \text { cukup sederhana }\end{array}$ sehingga kurang efektif karena hanya melalui pihak internal perusahaan dan melalui media sosial. Pihak internal yaitu teman, kerabat atau keluarga dari seluruh karyawan perusahaan. Selain itu juga promosi dilakukan lewat brosur yang disebarkan kepada masyarakat. Promosi melalui koran tidak dilakukan karena membutuhkan biaya yang cukup besar.

Selanjutnya menstrukturkan

untuk masalah-masalah diatas digunakan instrument SWOT. Analisis SWOT merupakan suatu alat yang efektif untuk membantu kita dalam menyelesaikan masalah terutama dengan melaksanakan analisis atas lingkungan internal dan eksternal pada PT. HTI Mandiri Palembang. Dalam lingkungan internal dan eksternal pada dasarnya terdapat beberapa hal pokok yang dapat disimpulkan. Pada lingkungan iternal perusahaan memiliki sejumlah kekuatan (Strength) dan kelemahan (Weakness) dan secara ekstrenal akan berhadapan dengan berbagai peluang (Oportunities) dan ancaman (Threat).

\section{B. Rumusan Masalah}

Perumusan masalah dalam penelitian ini adalah bagaimana bauran pemasaran produk rumah pada PT. HTI Mandiri Palembang dan bagaimana strategi bauran pemasaran yang telah diterapkan perusahaan.

\section{Pembatasan Masalah}

Agar penelitian ini tidak menyimpang maka penulis membatasi ruang lingkup masalah hanya pada analisis bauran pemasaran produk rumah type 55 dan type 88 pada PT. HTI Mandiri Palembang.

\section{Kerangka Pemikiran}

Kerangka pemikiran dari penelitian ini dapat digambarkan sebagai berikut :

\section{Gambar 1 \\ Kerangka pemikiran}

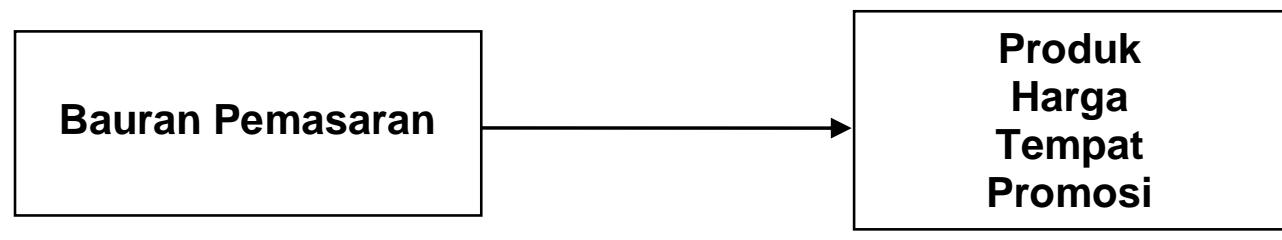

\section{E. Metode Penelitian}

Metode yang digunakan dalam penelitian ini adalah metode penelitian analisis kualitatif. Istijanto (2009:93) mendefinisikan analisi kualitatif bersifat memaparkan secara mendalam hasil riset melalui pendekatan bukan angka atau nonstatistik.

Peneitian dilakukan dengan menggunakan metode penelitian analisis kualitatif dimana analisis dilakukan dengan cara memaparkan dan menjelaskan bauran pemasaran yang ada pada PT. HTI Mandiri Palembang.

\section{F. Teknik Pengumpulan Data}

Teknik Pengumpulan data yang dilakukan dalam penelitian ini adalah :

1. Observasi merupakan pengumpulan data yang dilakukan dengan mengadakan pengamatan secara langsung kepada objek yang diteliti.

2. Wawancara merupakan metode yang digunakan untuk memperoleh informasi secara 
langsung, mendalam, tidak terstruktur dan individual.

3. Dokumentasi adalah data yang diperoleh dari perusahaan yang berupa catatan, dokumen dan keterangan tertulis lainnya mengenai hal-hal yang berhubungan dengan penelitian ini.

\section{G. Teknik Analisis Data}

Teknik analisis yang digunakan dalam penelitian ini adalah analisis deskriptif kualitatif. Teknik analisis deskriptif kualitatif bertujuan untuk mengungkap fakta, keadaan, fenomena, variabel dan keadaan yang terjadi saat penelitian berjalan dan penyuguhan apa adanya. Analisis SWOT adalah melaksanakan analisis atas lingkungan internal dan eksternal perusahaan. Lingkungan internal memiliki sejumlah kekuatan (Strenght) dan kelemahan (Weakness) atau analisis kekuatan dan kelemahan kemudian eksternal akan berhadapan dengan berbagai peluang (Opportunities) dan ancaman (Threats) atau analisis peluang dan ancaman.

Strategi berdasarkan analisis SWOT menjelaskan kombinasi antara beberapa situasi sebagai berikut :

1. (Kekuatan, kesempatan atau S-O) artinya perusahaan menentukan strategi berdasarkan kombinasi kekuatan dan kesempatan yang bisa memanfaatkan kekuatan untuk menggunakan peluang sebaik-baiknya.

2. (Kelemahan, Kesempatan atau $\mathrm{W}-\mathrm{O})$ artinya perusahaan harus membuat strategi bagaimana meminimakan kelemahan yang selalu muncul dalam perusahaan dengan memanfaatkan peluang yang menguntungkan.

3. (Kekuatan, Ancaman atau S-T) artinya perusahaan bisa memanfaatkan kekuatan baik dalam hal manajemen, sistem pemasaran maupun kemampuan finansial untuk mengatasi ancaman.

4. (Kelemahan, Ancaman atau W-T) artinya perusahaan harus meminimalkan kelemahan atau menghindari ancaman.

\section{H. Hasil Penelitian}

1) Kegiatan

Pemasaran

\section{Perusahaan}

William Y. Stanton dalam Kurniawan (2014:12) mendefinisikan pemasaran sebagai suatu yang meliputi seluruh sistem yang berhubungan dengan tujuan untuk merencanakan dan menentukan harga sampai dengan mempromosikan dan mendistribusikan barang dan jasa yang bisa memuaskan kebutuhan pembeli aktual maupun potensial. Strategi pemasaran sangat dibutuhkan untuk mencegah penurunan jumlah konsumen serta jatuhnya daya saing produk bisnis di pasar. Strategi merupakan daya kreatifitas dan daya cipta (inovasi) serta merupakan cara pencapaian tujuan yang sudah ditentukan oleh pimpinan puncak perusahaan sedangkan fokus pada pemasaran dilakukan oleh manajer pemasaran. Strategi pemasaran yang menyatu merupakan rangkaian proses pemasaran secara lebih maksimal. Tanpa adanya pemasran yang teruji, dapat dipastikan pemasaran akan jatuh, terlebih lagi apabila muncul berbagai produk kompetitif yang dikeluarkan oleh pesaing-pesaing bisnis.

\section{2) Target Penjualan}

Proses pembangunan rumah yang dibangun oleh PT. HTI Mandiri Palembang yaitu Komplek Tiga Putri Kencana tahun 2017 terdiri dari 16 Blok dan yang telah terjual sebanyak $80 \%$ dari total seluruh blok yang dibuat selama proses pembangunan komplek tersebut. Hal ini menjadi pemicu 
perusahaan untuk meningkatkan persentase penjualan pada proyek pembangunan berikutnya dengan persentase minimal $100 \%$ rumah yang terjual dari total keseluruhan rumah yang dibangun. Hal itu dapat terlihat dari Layout perumahan PT. HTI Mandiri Palembang pada gambar 3 berikut ini.

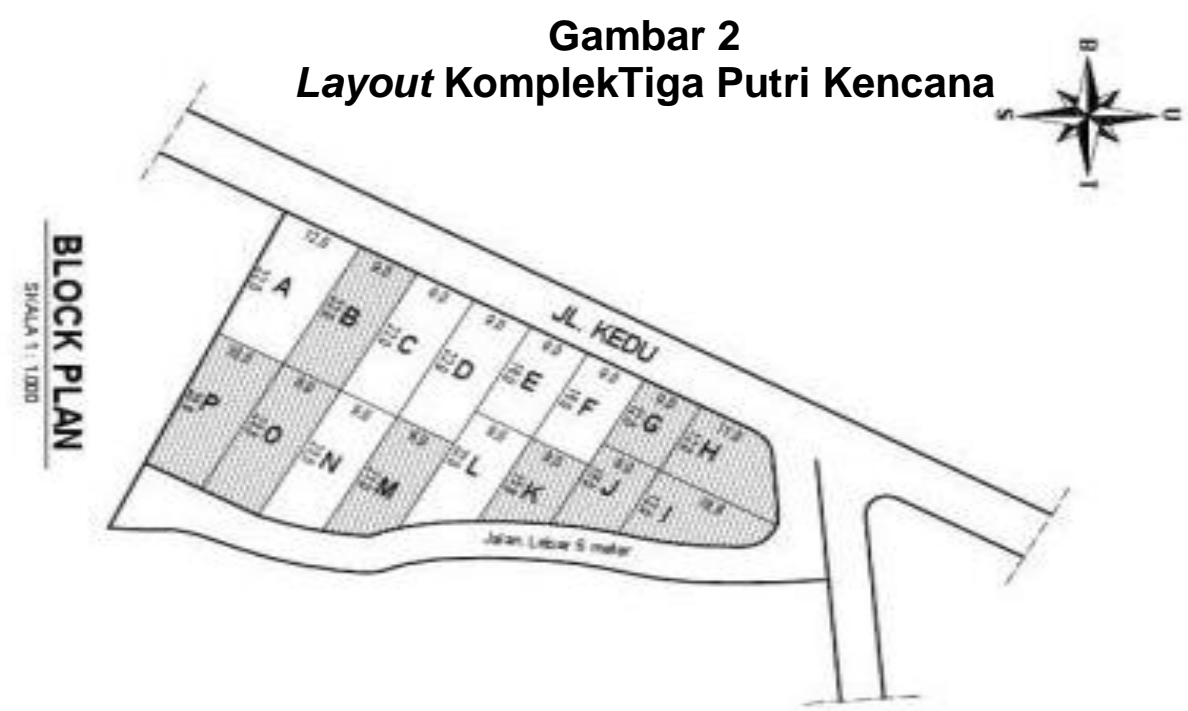

Sumber : PT. HTI Mandiri Palembang Tahun 2017

3) Strategi Bauran Pemasaran PT. HTI Mandiri Palembang

3.1. Kebijakan Produk

Didalam

mengembangakan

sebuah program untuk mencapai pasar yang diinginkan, maka perusahaan perlu merancang produk apa yang dapat memuaskan keinginan pasar. Para pemimpin harus merencanakan, mengembangkan serta mengelola produk perusahaan baik secara gabungan maupun secara pribadi. Tugas ini bukanlah tugas yang mudah terbukti dengan banyaknya produk yang gagal menembus pasar yang ada.

Setiyaningrum Dkk (2015:82) mendefinisikan produk sebagai suatu kumpulan atribut fisik, psikis, jasa dan simbolik yang dibuat untuk memuaskan kebutuhan dan keinginan pelanggan. Sedangkan Hermawan (2012:36) mendefinisikan produk sebagai objek yang sangat vital yang mempengaruhi keberhasilan perusahaan dalam mendatangkan tingkat keuntungan atau laba yang akan tetap menjaga aktifitas operasional dan kesehatan keuangan perusahaan.

Produk merupakan salah satu elemen marketing mix yang merupakan suatu usaha perusahaan untuk memproduksi yang akhirnya menghasilkan dan menjual berbagai jenis barang dengan berbagai macam variasi. Hal ini menjadi harapan perusahaan untuk memenuhi keinginan konsumen, seseorang dalam membeli suatu produk akan melakukan pertimbangan kebutuhannya, mengenai manfaat dari produk itu sendiri dan apakah produk tersebut akan memenuhi kebutuhan dan memuaskan keinginannya.

Dalam melaksanakan kebijakan produk yang baik maka ada beberapa faktor yang perlu dipertimbangkan dan di analisis yaitu :

a) Kegunaan inti produk

$\mathrm{Hal}$ yang terpenting dalam suatu kegiatan yang dilakukan adalah harus mengetahui keguanaan inti dari apa yang akan dibuat atau dilakukan. 
Rumah dalam hal ini merupakan hal penting bagi masyarakat serta memiliki kegunaan inti yaitu sebagai tempat berlindung, tempat beristirahat, tempat berkumpul, tempat bersosialisasi dalam kehidupan manusia seutuhnya sehingga harus memperhatikan faktorfaktor vital dalam proses pembangunan rumah.

b) Kualitas Produk

Keberhasilan perusahaan dalam meningkatkan pemasaran produk tidak terlepas dari kualitas produk yang dipasarkannya. Kalau kualitas produk yang dipasarkan memiliki kaulitas yang tinggi maka akan mudah bagi perusahaan tersebut untuk memasarkan produknya. Begitupun sebaliknya apabila produk yang dipasarkan oleh suatu perusahaan berkualitas rendah maka sulit bagi perusanaan untuk memasarkan produknya. Kualitas tidak hanya dilihat dari corak, bentuk atau kemasan rumah saja tetapi juga dari cara pembuatan yang baik dan benar serta menggunakan bahan dengan kualitas yang bagus dan layak dipakai.

c) Pengembangan Produk

Pengembangan produk juga merupakan hal yang tidak dapat dipisahkan dari keberhasilan suatu perusahaan dalam usahanya untuk meningkatkan pemasaran produk rumah PT. HTI Mandiri Palembang. Pengembangan produk dari produk yang telah ada akan menciptakan minat konsumen untuk mencoba produk yang baru dikembangkan tersebut. Selalu berinovasi serta berusaha tampil beda dengan produk yang dibuat oleh perusahaan pesaing.

Ada tiga keuntungan bagi perusahaan yang melakukan pengembangan produk, yaitu :

1) Keinginan Konsumen

Mengetahui keinginan konsumen juga penting untuk pengembangan produk yang dilakukan oleh suatu perusahaan, berarti perusahaan telah menciptakan produk sesuai dengan selera konsumen karena konsumen akan selalu berkeinginan untuk mencoba produk-produk baru yang dikembangkan tersebut.

2) Kebutuhan Konsumen

Memperhatikan kebutuhan konsumen merupakan hal terpenting karena konsumen akan mendahulukan kebutuhannya dari pada keinginanya. Apabila konsumen telah mencoba produk yang telah dikembangkan oleh perusahaan dan konsumen tersebut telah merasakan manfaat yang tinggi dari produk tersebut maka produk tersebut telah menjadi kebutuhan bagi konsumen. Pada tahap ini konsumen akan melakukan pembelian ulang terhadap produk tersebut.

3) Daya Saing

Keberhasilan suatu perusahaan dalam mengembangkan produknya akan menciptakan daya saing yang tinggi bagi perusahaan dalam memasarkan produknya. Pengembangan produk merupakan suatu proses penciptaan atau penyempurnaan suatu produk yang telah ada. Pengembangan produk merupakan suatu hal yang sangat penting dan harus menjadi perhatian bagi setiap perusahaan untuk meningkatkan pemasaran produknya. Berdasarkan jenis dari produknya maka produk rumah PT. HTI Mandiri Palembang merupakan produk yang memiliki banyak tipe. Tipe produk selalu mengalami perkembangan, baik corak, bentuk maupun fungsinya. 
Karena perkembangan tersebut maka diperlukan suatu kemampuan yang dapat menciptakan pembaharuan yang berorientasi pada selera konsumen. Bentuk produk yang menarik akan mengundang selera dari para konsumen untuk memilikinya.

\subsection{Kebijakan Harga}

Dalam usaha meningkatkan pemasaran produk dan memperluas pasar, suatu perusahaan harus mengambil kebijakan harga yang bertujuan untuk mencapai laba yang diinginkan melalui kepuasan konsumen.

Sedangkan tujuan dari penentuan harga itu sendiri adalah :

a. Memperoleh Keuntungan yang Optimal

Apabila penetapan harga dibuat dengan benar antara biaya saat proses pembuatan serta biaya dalam proses penjualan maka perusahaan akan mendapatkan keuntungan yang optimal.

b. Menghadapi atau Mencegah Persaingan

Apabila perusahaan tidak dalam lingkup yang benar dan menegtahui harga pasar produk yang dibuatnya maka hal ini akan berdampak kerugian bagi perusahaan. Harga yang ditentukan sesuai dengan produk yang dibuat sehingga tidak merugikan konsumen.

c. Image Perusahaan

Jika perusahaan terlalu tinggi dalam menentukan harga maka image yang akan timbul di mata masyarakat adalah bahwa perusahaan tersebut tidak profesional karena harga tidak sesuai dengan jenis produk yang dibuat. Begitu juga jika harga yang dibuat terlalu rendah maka masyarakat akan menilai perusahaan tersebut tidak dalam kualitas yang seharusnya.

Seperti yang telah diulas pada halaman sebelumnya bahwa pada umumnya perusahaan melakukan penjualan langsung kepada konsumen sehingga dapat meminimalisasi harga jual akhir produk dan hal ini merupakan strategi harga yang baik untuik menghadapi persaingan dalam bidang yang serupa yang menggunakan perantara.

\subsection{Kebijakan Tempat atau Lokasi}

Kebijakan tempat atau lokasi merupakan suatu faktor yang penting yang harus dilakukan oleh suatu perusahaan, karena lokasi merupakan faktor penting dalam proses pemasaran perusahaan secara efektif untuk menarik minat konsumen dan mendapatkan laba tentunya.

Dalam prosesnya perusahaan selalu memilih tempat atau lokasi yang diinginkan konsumen karena lokasi yang tepat akan dengan cepat menarik minat konsumen terhadap produk yang dibuat oleh perusahaan.

Ada beberapa faktor yang sangat diperhatikan perusahaan dalam menentukan tempat atau lokasi antara lain :

a. Kepadatan penduduk

Lokasi yang dipilih perusahaan selalu berada dalam kondisi yang ramai penduduknya karena akan membantu konsumen yang akan tinggal di rumah tersebut mudah mendapatkan apa yang dia butuhkan.

b. Akses jalan

Lokasi rumah yang berada dekat dengan jalan protokol akan sangat membantu mempermudah konsumen untuk melakuka kegiatan sehari-hari.

c. Aman dan bersih 
Lokasi yang aman dan bersih akan membuat konsumen merasa nyaman tinggal di rumah yang dia beli.

\subsection{Kebijakan Promosi}

Dalam usaha untuk memperkenalkan produknya kepada masyarakat agar produk tersebut dikenal kemudian diminati dan akhirnya dibeli dan untuk meningkatkan pemasaran produk suatu perusahaan maka promosi juga memegang peranan penting karena betapapun bermanfaat suatu barang tanpa adanya upaya untuk memperkenalka kepada masyarakat maka kegiatan pemasaran tersebut tidak akan berhasil karena produk tersebut tidak mampu menemukan sendiri pembelinya. Permintaan akan hasil produksi harus diciptakan, dipelihara dan dikembangkan. Dengan kata lain setiap produk membutuhkan promosi.

Dari observasi yang penulis lakukan dapat diketahui bahwa kegiatan promosi yang dilakukan PT. $\mathrm{HTI}$ Mandiri Palembang tidak begitu gencar atau apa adanya. Kegiatan promosi dengan memanfaatkan pihak internal perusahaan, media sosial dan brosur yang jumlahnya terbatas.

\section{4) Analisis SWOT}

Evaluasi terhadap keseluruhan kekuatan (strength), kelemahan (weakness), peluang (opportunities) dan ancaman (threat) perusahaan disebut analisis SWOT.

\subsection{Analisis Lingkungan Internal (Analisis Kekuatan dan Kelemahan)}

Selain mengetahui peluang yang menarik di lingkungannya, unit bisnis perlu juga memiliki keahlian tertentu supaya berhasil memanfaatkan peluang tersebut. Tiap-tiap unit bisnis harus mengevaluasi kekuatan dan kelemahan secara periodik. Jelas, unit bisnis perlu memperbaiki kelemahannya dan tidak perlu merasa bangga dengan setiap kekuatannya. Kadang-kadang unti bisnis tertentu gagal bukan karena departemendepartemennya tidak memiliki kekuatan yang dibutuhkan melainkan karena mereka tidak bekerja sama dengan baik sebagai tim. Karena kerjasama yang baik dalam tim akan membangun suasana yang nyaman antara departemen yang ada dalam unit tersebut dan dapat menghasilkan semangat kerja keras untuk memenuhi target perusahaan.

\subsection{Analisis Lingkungan Eksternal (Analisis Peluang dan Ancaman)}

Umumnya unit bisnis harus juga memantau lingkungan eksternal yang menjadi penentu (demografi-ekonomi, teknologi, politik-hukum, dan sosialbudaya) dan pelaku lingkungan eksternal utama (pelanggan, pesaing, saluran distribusi, pemasok) yang berdampak pada kemampuan memperoleh laba. Unit bisnis tersebut harus membentuk sistem intelijen pemasaran untuk memantau tren dan perkembangan penting yang lain. Terhadap masing-masing tren dan perkembangan itu, manajemen perlu mengindentifikasi peluang dan ancaman yang terkait.

Tujuan utama pengamatan lingkungan adalah melihat dengan jeli peluang pemasaran baru. Peluang pemasaran adalah wilayah kebutuhan atau potensi minat pembeli dimana perusahaan dapat menggarapnya secara menguntungkan. Bentuk peluang itu bermacam-macam dan perusahaan harus bisa mengenalinya dengan cara :

a. Perusahaan bisa membuat proses pembelian menjadi nyaman dan efisien menggunakan situs Web yang dibuat oleh perusahaan 
mengingat sekarang jaman semakin canggih dengan kemajuan teknologi.

b. Perusahaan dapat menyesuaikan dengan kebutuhan atas produk yang sebelumnya hanya ditawarkan dalam bentuk standar.

c. Perusahaan dapat memperkenalkan produk barunya dengan cepat ke pasaran dengan cara mempostingnya melalui akun perusahaan.

\section{5) SWOT dalam PT. HTI Mandiri} Palembang

\subsection{Kekuatan (Strenght)}

Sebagaimana telah diuraikan sebelumnya bahwa yang dimaksud dengan faktor-faktor kekuatan yang dimiliki oleh suatu perusahaan termasuk satuan-satuan bisnis didalamnya adalah kompetensi khusus yang didapat dalam organisasi yang berakibat pada pemilikan keunggulan komparatif oleh unit usaha di pasaran. Dikatakan demikian karena suatu bisnis memiliki sumber, keterampilan, produk andalan dan sebagainya yang membuatnya lebih kuat dari pesaing dalam memuaskan kebutuhan pasar yang sudah ada. Contoh-contoh bidang keunggulan itu antara lain ialah kekuatan pada sumber keuangan, citra positif, keunggulan kedudukan dipasar, hubungan dengan pemasok bahan baku dan kepercayaan dari berbagai pihak yang berkepentingan.

Bila dihubungkan dengan PT. HTI Mandiri Palembang, maka faktor-faktor kekuatan yang dimilikinya antara lain sebagai berikut :

a. Produk

1) Produk rumah yang dibuat oleh PT. HTI Mandiri Palembang selalu up to date sesuai dengan perkembangan zaman.
2) Bahan-bahan yang digunakan untuk pembangunan rumah merupakan bahan yang berkualitas baik.

3) Desain dan warna rumah selalu mengikuti perkembangan jaman (modern) serta rumah dikemas dalam bentuk yang menarik minat konsumen dengan menambahkan sentuhan-sentuhan interior ruangan sebagai alat pemanis rumah yang dibangun.

b. Harga

1) Perusahaan menetapkan kebijakan penjualan secara tunai dan kredit dengan persyaratan yang mudah.

2) Harga yang ditetapkan oleh perusahaan bersaing dengan harga yang dibuat oleh pesaing sesuai dengan tipe rumah dan luas tanah.

3) Pada umumnya PT. HTI Mandiri Palembang dalam memasarkan produknya tidak menggunakan perantara atau pihak ke-3 sehingga saluran distribusinya pendek dan hal tersebut baik dalam meminimalisir tingkat harga produk.

4) Berlaku potongan harga kepada masyarakat yang memesan rumah saat proses pembangunan rumah baru dilaksanakan atau belum dilaksanakan (masih tahap pematangan lahan)

Dibandingkan dengan harga perusahaan lain, rumah PT. HTI Mandiri Palembang bisa dikatakan cukup bersaing. Hal ini dapat dilihat dari daftar harga rumah PT. HTI Mandiri Palembang dengan harga rumah perusahaan pesaing pada tabel 2 berikut. 
Tabel 2

Harga Rumah Produk Pesaing

\begin{tabular}{|c|c|c|c|}
\hline Nama PT & Type rumah & Luas tanah & Harga (Rp) \\
\hline PT. HTI Mandiri & 55 & $108 \mathrm{~m}^{2}$ & 499.000 .000 \\
Palembang & 88 & $241 \mathrm{~m}^{2}$ & 1.110 .000 .000 \\
& Town House & $144 \mathrm{~m}^{2}$ & 1.139 .000 .000 \\
\hline PT. Silampari & 55 & $105 \mathrm{~m}^{2}$ & 476.120 .000 \\
Indah & 88 & $120 \mathrm{~m}^{2}$ & 879.000 .000 \\
& Town House & $150 \mathrm{~m}^{2}$ & 1.154 .211 .000 \\
\hline PT. Citra & 55 & $105 \mathrm{~m}^{2}$ & 488.750 .000 \\
Bangun Perkasa & 88 & $175 \mathrm{~m}^{2}$ & 909.650 .000 \\
& Town House & $162 \mathrm{~m}^{2}$ & 1.166 .962 .000 \\
\hline
\end{tabular}

Perbandingan persentasi anatar PT. HTI Mandiri Palembang dengan PT. Istana Kenten Indah Palembang dan PT. Prabu Griya Utama.

$>$ Rumah type 55 (PT. HTI) Rp. 499.000.000,- - Rp. 476.120.000.(PT.SI) =

Rp. $\frac{22.880 .000}{499.000 .000 .}=0,04 \times 100 \%=4 \%$

$>$ Rumah type 88 (PT. HTI) Rp. 1.110.000.000.,- - Rp. 879.000.000,- $\quad$ (PT. SI) $=\frac{231.000 .000}{1.110 .000 .000}=0,21 \times 100 \%=21 \%$

$>$ Rumah type Town House (PT.HTI) Rp. 1.139.000.000,- Rp. 1.154.211.000,- (PT.SI) = $\frac{-12.211 .000}{1.139 .000 .000}=-0,01 \times 100 \%=-1 \%$

Rumah type 55 (PT. HTI) Rp. 499.000.000,- - Rp. 488.750.000.$(\mathrm{PT} . \mathrm{CBP})=$

Rp. $\frac{10.250 .000}{499.000 .000 .}=0,02 \times 100 \%=2 \%$

$>$ Rumah type 88 (PT. HTI) Rp. 1.110.000.000,- - Rp. 909.650.000.- (PT.CBP) $=$

Rp. $\frac{200.350 .000}{1.110 .000 .000 .}=0,18 \times 100 \%=$ $18 \%$

$>$ Rumah type Town House (PT. HTI) Rp. 1.139.000.000,- - Rp. 1.166.962.000.- (PT.CBP) $=$ Rp. $\frac{-27.962 .000}{1.139 .000 .000}=-0,02 \times 100 \%=-2 \%$

Dari data tersebut dapat disimpulkan bahwa selisih perbedaan harga antara PT. HTI Mandiri
Palembang dengan pesaing yaitu PT. Silampari Indah dan PT. Citra Bangun Perkasa tidak terlalu besar sesuai dengan tipe dan luas tanah.

a. Tempat atau lokasi

1) Lokasi yang dipilih dalam pembangunan rumah cukup strategis yaitu dekat dengan perkotaan dan kebutuhan masyarakat seperti sekolah, pasar, bandara dan lain-lain.

2) Selain lokasi yang cukup strategis, pemilihan tempat dalam pembangunan rumah juga memperhatikan faktor penting lainnya seperti keamanan, kenyamanan dan jauh dari kebanjiran.

3) Pemilihan lokasi juga disesuaikan dengan target atau pangsa pasar yang dituju, karena jika tidak tepat sasaran yang diinginkan maka rumah akan mengalami masalah dalam proses penjualan.

b. Promosi

1) Dalam melakukan kegiatan promosi, perusahaan menggunakan brosur penjualan yang disebar kemasyarakat.

2) Selain itu juga, perusahaan memakai pihak internal perusahaan dalam melakukan promosinya sehingga tidak banyak memakan biaya 
3) Selain memakai pihak internalnya, perusahaan juga memanfaatkan media sosial untuk mendukung kegiatan promosinya

Jaman sekarang sudah sangat canggih sehingga dalam memilih lokasi penjualan harus memperhatikan fasilitas pendukung yang meliputi ketersediaan wifi, hot spot yang mudah diakses, area hijau, instalasi listrik dan air. Sumarni dan Soeprihanto (2010:288) mendefinisikan saluran distribusi sebagai saluran yang digunakan oleh produsen untuk menyalurkan produk tersebut dari produsen ke konsumen atau industri pemakai.

\subsection{Kelemahan (Weakness)}

Jika orang berbicara tentang kelemahan yang terdapat dalam satuan bisnis yang dimaksud adalah keterbatasan atau kekurangan dalam hal sumber keterampilan, dan kemampuan yang menjadi penghalang serius bagi kinerja perusahaan. Berbagai kekurangan dan keterbatasan tersebut dapat dilihat pada sarana dan prasarana yang dimiliki, kemampuan menejerial yang rendah, keterampilan pemasaran yang tidak sesuai dengan tuntutan pasar, produk yang kurang diminati oleh masyarakat dan perolehan tingkat keuntungan yang tidak sesuai dengan yang diharapkan.

Sebagaimana yang telah terjadi saat ini yaitu tingkat penggunaan yang tinggi dan hal tersebut memberikan kepada masyarakat yang lebih untuk memilih, karena jumlah dan macammacam produk yang kapasitasnya terus bertambah. Agar para konsumen tidak beralih dari hasil produksi PT. HTI Mandiri Palembang maka perusahaan ini harus mengupayakan agar strategi bauran pemasarannya dapat semakin solid dan mampu memaksimalkan laba yang akan diperoleh tetapi juga dapat meminimalisir kelemahan yang ada. Dari hasil analisis, penulis melihat beberapa kelemahan yang ada pada perusahaan ini antara lain :

a. Produk

1) Jumlah unit rumah yang dibuat terbatas.

2) Akan ada biaya tambahan jika ingin merubah konsep dan desain rumah.

3) Mayoritas rumah yang dibuat bertipe real estate (untuk kalangan menegah keatas)

b. Harga

1) Melemahnya nilai tukar Rupiah terhadap Dollar sangat mempengaruhi harga perumahan karena tingkat suku bunga bank akan naik sehingga masyarakat enggan dalam membeli produk rumah yang di buat perusahaan karena perusahaan akan menaikkan harga rumah seiring dengan biaya bahan baku yang digunakan dalam proses pembangunan juga mengalami kenaikan.

2) Konsumen tidak mendapatkan potongan harga jika membeli rumah yang sudah selesai dibangun.

3) Tingkat pendapatan masyarakat Palembang yang tidak merata sehingga masyarakat lebih memilih mengontrak rumah dari pada harus membeli karena tidak memiliki uang yang cukup.

c. Tempat atau Lokasi

1) Sulit mendapatkan lokasi yang diinginkan seperti di dalam lingkup perkotaan mengingat kota Palembang sekarang sudah cukup dipenuhi oleh perusahaan yang bergerak dibidang yang sama.

2) Butuh biaya yang cukup besar untuk mendapatkan lokasi yang strategis. 
d. Promosi

1) Jangkauan promosi tidak terlalu luas.

2) Karena tidak menggunakan media cetak seperti koran dan media elektronik seperti iklan di radio maka masih banyak masyarakat yang belum mengetahui perusahaan ini dan produk yang dibuatnya.

3) Promosi yang tidak terlalu gencar.

\subsection{Peluang (Opportunity)}

Peluang adalah berbagai situasi lingkungan yang menguntungkan bagi perusahaan, yang dimaksud dengan berbagai situasi lingkungan yang menguntungkan yaitu :

a. Pangsa Pasar yang Masih Luas

Pangsa pasar yang masih luas di Sumatera Selatan merupakan peluang besar bagi perusahaan mendapatkan konsumen baru untuk membeli produk yang dibuat perusahaan.

b. Rumah Merupakan Kebutuhan Pokok Masyarakat

Rumah merupakan salah satu kebutuhan pokok masyarakat, semakin besarnya perkembangan hidup masyarakat maka kebutuhan akan rumah semakin meningkat.

c. Rumah Sebagai Alat Investasi

Selain sebagai kebutuhan pokok, rumah juga merupakan alat investasi yang paling banyak diminati karena memberikan keuntungan yang besar. Banyak masyarakat yang memanfaatkan rumah sebagai alat investasi karena harga rumah tiap harinya selalu naik dari harga beli dan bisa kontrakan atau rumah kos yang mendatangkan keuntungan.

d. Harga Rumah yang Terus Meningkat
Sudah tidak mengagetkan jika harga rumah pasti akan selalu meningkat setiap harinya. Hal ini sangat menguntungkan bagi perusahaan karena akan terjadi kenaikan laba jika rumah yang mereka buat dibeli dalam waktu beberapa tahun yang akan datang mengingat tidak perlu banyak perawatan untuk menjaga kualitas rumah.

\subsection{Ancaman (Threat)}

Ancaman merupakan kebalikan dari peluang. Dengan demikian, dapat dikatakan bahwa ancaman adalah faktor-faktor lingkungan yang tidak menguntungkan perusahaan. Jika tidak diatasi, ancaman akan menjadi ganjalan bagi perusahaan baik disaat sekarang maupun yang akan datang.

\section{a. Pesaing Baru}

Semakin besarnya tingkat kebutuhan bagi masyarakat maka akan semakin banyak permintaan yang dilakukan oleh masyarakat akan rumah. Hal ini selain memberikan keuntungan juga memberikan ancaman bagi perusahaan karena peluang yang menjanjikan dalam bidang properti akan membuat masyarakat berbondong-bondong untuk membuat atau mendirikan perusahaan dalam bidang yang sama. Serta kesuksesan suatu perusahaan pasti akan diikuti bahkan ditiru oleh perusahaan lainnya guna memenuhi target perusahan mereka.

b. Cara Pandang Masyarakat dalam Menilai Produk

Cara pandang masyarakat dalam menilai produk juga merupakan ancaman bagi perusahaan karena semakin detailnya masyarakat dalam menilai produk akan membuat masyarakat rinci dalam memilih produk, sedikit saja kekurangan yang terdapat pada 
rumah yang dibuat maka masyarakat akan beralih ke produk rumah yang dibuat oleh perusahaan lain.

c. Trend Masyarakat yang Cepat Berubah

Keinginan masyarakat yang beragam dan cepat berubah akan membuat ancaman bagi perusahaan jika produk yang dibuat perusahaan tidak sesuai selera masyarakat yang seiring berkembangnya jaman ingin memiliki rumah yang modern dan up to date.

d. Disrtibusi Pendapatan Masyarakat yang Tidak Merata

Faktor lain sering dilupakan perusahaan dalam menentukan produk dan harga adalah distribusi pendapatan masyarakat yang tidak merata sehingga tidak semua masyarakat bisa membeli rumah yang dibangun perusahaan. Selain itu, masyarakat berpenghasilan kecil lebih memilih untuk mengontrak rumah dari pada harus membeli rumah meskipun dengan tipe dan ukuran yang kecil.

\subsection{Matriks SWOT}

Matriks SWOT disusun berdasarkan hasil identifikasi faktor internal dan eksternal perusahaan yang menggambarkan kekuatan dan kelemahan yang dimiliki perusahaan serta peluang dan ancaman yang dihadapi perusahaan. Matriks SWOT yaitu kombinasi faktor internal yang menggambarkan kekuatan dan kelemahan yang dimiliki perusahaan dengan faktor eksternal yang menggambarkan peluang dan ancaman yang akan dihadapi perusahaan. Kombinasi dari faktor internal dan eksternal perusahaan disususun secara sistematis dan terstruktur sehingga menghasilkan 4 macam strategi yaitu strategi S-O, S-T, W-O, dan W-T. Strategi yang dihasilkan dari matriks SWOT dapat dilihat pada gambar 3 .

\section{Gambar 3 \\ Matriks SWOT}

\begin{tabular}{|l|l|l|}
\hline \multicolumn{2}{|c|}{ STRENGTH (S) } & \multicolumn{2}{c|}{ WEAKNES (W) } \\
1. $\begin{array}{l}\text { Memiliki produk rumah yang } \\
\text { up to date } \\
\text { Bahan baku produk } \\
\text { berkualitas baik }\end{array}$ & 2. $\begin{array}{l}\text { Promosi masih kurang } \\
\text { meluas }\end{array}$ \\
3. $\begin{array}{l}\text { Proses kepemilikan rumah } \\
\text { yang cepat dan tepat }\end{array}$ & 3. $\begin{array}{l}\text { Sulit mendapan matkan lokasi } \\
\text { yang strategis dan luas }\end{array}$
\end{tabular}

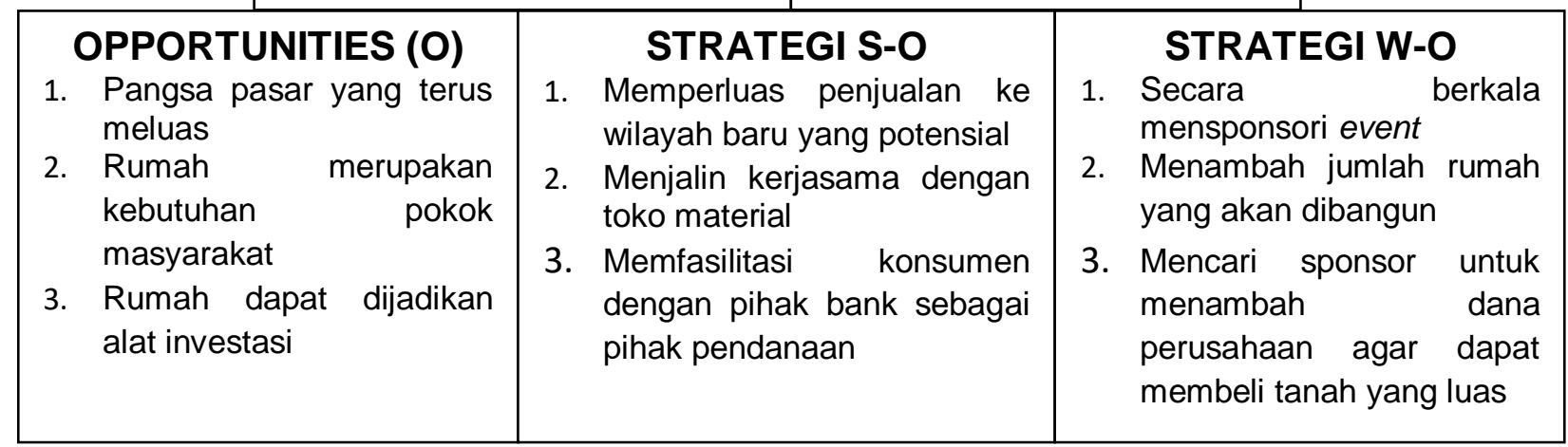




\begin{tabular}{|c|c|c|}
\hline $\begin{array}{l}\text { THREATHS }(\mathbf{T}) \\
\text { 1. Kompetitor baru } \\
\text { 2. Paradigma masyarakat } \\
\text { dalam menilai } \\
\text { keunggulan produk } \\
\text { 3. Keinginan masyarakan } \\
\text { yang cepat berubah }\end{array}$ & $\begin{array}{l}\text { STRATEGI S-T } \\
\text { 1. } \begin{array}{l}\text { Mementingkan kesesuaian } \\
\text { harga dengan kualitas rumah }\end{array} \\
\text { 2. } \begin{array}{l}\text { Menjaga kepercayaan } \\
\text { konsumen terhadap mutu }\end{array} \\
\begin{array}{l}\text { produk perusahaan } \\
\text { 3. }\end{array} \\
\begin{array}{l}\text { Menjembatani animo } \\
\text { masyarakat terhadap } \\
\text { produksi rumah yang } \\
\text { diinginkan }\end{array}\end{array}$ & $\begin{array}{l}\text { STRATEGI W-T } \\
\text { 1. Meningkatkan promosi di } \\
\text { media masa, elektronik } \\
\text { maupun media sosial } \\
\text { 2. Selalu menjaga kualitas } \\
\text { rumah yang dibangun } \\
\text { 3. Lebih tepat dalam } \\
\text { menentukan pangsa pasar } \\
\text { yang diinginkan }\end{array}$ \\
\hline
\end{tabular}

Penjelasan yang lebih rinci mengenai strategi yang dihasilkan dari matrik :

\section{Strategi S-O (Strength Opportunity) \\ Strategi S-O adalah strategi yang} menggunakan kekuatan internal perusahaan untuk meraih peluangpeluang yang ada diluar perusahaan yaitu :

a. Memperluas penjualan ke wilayah baru yang potensial. Hal ini harus dilakukan perusahaan karena produk rumah yang dibangun selalu up to date dan pangsa pasar yang terus meluas dengan memperluas penjualan ke wilayah baru akan membuat perusahaan lebih dikenali oleh masyarakat dan produk yang di hasilkan lebih banyak diminati masyarakat sehingga peruahaan akan mendapat laba yang lebih besar.

b. Menjalin kerjasama dengan toko material untuk kelancaran dalam proses pembangunan maka perusahaan harus bisa menjaga hubungan baik dengan toko material yang telah dipilih perusahaan supaya dapat memenuhi bahanbahan bangunan yang diingikan karena jika tidak memiliki hubungan yang baik dengan toko material tersebut maka akan berdampak pada terhambatnya proses pengiriman barang bangunan ke lokasi pembangunan rumah yang sedang di bangun.

c. Mengadakan kerjasama dengan lembaga pembiayaan yang dapat diandalkan dengan pemberian reward tertentu bagi lembaga pembiayaan tersebut jika meraih target yang ditentukan perusahaan.

Strategi ini dilakukan dengan
menggunakan
kekuatan dari
perusahan dan memanfaatkan peluang yang cukup untuk melakukan pelayanan terhadap calon konsumen. Karena jika kita menjalin hubungan baik dengan calon konsumen maka calon konsumen tersebut akan memiliki rasa yang simpatik yang bisa membuatnya tertarik dengan produk yang kita tawarkan atau bahkan membantu promosi perusahaan tanpa harus kita minta. Hubungan baik dengan konsumen yang ada terus dipertahankan sebagai saluran distribusi perusahaan untuk meningkatkan penjualan. Kekuatan lainnya yaitu memiliki beragam produk, harga, lokasi baru sehingga memudahkan calon konsumen dalam menentukan jenis rumah yang menjadi pilihannya.

\section{Strategi S-T (Strength-Threath)}

Strategi S-T adalah strategi yang menggunakan kekuatan internal perusahaan untuk menghindari atau mengurangi dampak dan ancamanancaman yang berasal dari luar 
perusahaan. Menciptakan produk yang berkualitas dengan melakukan inovasi berkesinambungan melalui penggunaan bahan baku yang baik dan teknologi yang canggih. Langkah yang dapat dilakukan perusahaan yaitu :

a. Mementingkan kesesuaian harga dengan kualitas rumah yang dibangun karena jika perusahaan salah dalam menentukan harga yang tidak sesuai dengan kualitas rumah yang dibangun maka akan membuat image perusahaan dimata masyarakat menjadi negative

b. Selain membuat rumah dengan desain yang modern dan up to date, perusahan juga harus selalu menjaga kualitas rumah karena kualitas rumah merupakan faktor vital dan faktor penting untuk mendapatkan kepuasan dari konsumen.

c. Membangun rumah yang sesuai dengan keinginan masyarakan yang selalu ingin memiliki rumah yang modern sesuai dengan perkembangan jaman tapi tetap menjaga kesesuaian harga dan lokasi yang di inginkan masyarakat.

Strategi ini dilakukan dengan memaksimalkan kekuatan untuk menghindari ancaman yang dihadapi perusahaan. Kekuatan yang dimaksimalkan pada strategi ini yaitu memiliki beragam produk rumah yang up todate dan dikemas dengan cantik dan menarik dengan dukungan proses kepemilikan rumah yang cepat dan tepat.

Ancaman yang dihadapi pada strategi ini yaitu paradigma masyarakat dalam menilai keunggulan produk yang dipengaruhi melalui acara atau event perusahaan lain. Ancaman lain yaitu masih minimnya pendapatan masyarakat di Kota Palembang yang lebih memilih mengontrak dari pada membeli rumah.
3. Strategy W-O (Weakness-Opportunity)

Strategi W-O adalah strategi yang dilakukan dengan memperkecil kelemahan internal perusahaan dan memanfaatkan peluang-peluang yang ada di luar perusahaan yaitu mesponsori event lokal. Langkah yang dapat dilakukan perusahaan yaitu :

a. Memasang nama perusahaan pada spanduk kegiatan olahraga sebagai sarana untuk promosi dan menjadi sponsor perlombaan atau kegiatan yang dilakukan masyarakat.

b. Berusaha menambah jumlah rumah yang akan dibagun karena tingginya tingkat kebutuhan masyarakat untuk memiliki rumah sendiri.

c. Mencari sponsor untuk menambah dana perusahaan agar dapat membeli tanah yang lebih luas dengan lokasi yang strategis sehingga dapat memenuhi keinginan masyarakat akan produk rumah yang mereka butuhkan.

Strategi ini dilakukan untuk memperkecil kelemahan yang dimiliki PT. HTI Mandiri Palembang serta memanfaatkan peluang yang ada dilingkungan masyarakat yaitu potensi pasar produk rumah yang masih luas serta semakin meningkatkan kebutuhan masyarakat akan rumah. Peluang tersebut memberikan motivasi bagi perusahaan untuk terus meningkatkan kegiatan pemasaran dalam rangaka peningkatan penjualan rumah serta menjaga dan meningkatkan citra perusahaan di mata masyarakat Palembang khususnya.

\section{Strategy W-T (Weakness-Threath)}

Strategi W-T adalah strategi untuk bertahan dengan cara mengurangi kelemahan internal serta menghindari ancaman yaitu meningkatkan pangsa pasar melalui penambahan pemasaran, jumlah iklan, promosi penjualan serta usaha publisitas. Langkah yang dapat dilakukan yaitu : 
a. Melakukan promosi pada media elektronik seperti radio di daerah Palembang dan sekitarnya untuk menjangkau konsumen yang lebih luas.

b. Menjaga kualitas rumah yang dibangun sehingga image perusahaan tetap baik dimata masyarakat karena kepercayaan masyarakat terhadap perusahaan merupakan salah satu faktor penting untuk mendapatkan konsumen baru.

c. Lebih bijak dalam menentukan pangsa pasar sehingga dalam proses penjualan perusahaan dapat mencapai target yang diinginkan.

Strategi ini dilakukan untuk meminimalkan kelemahan yang dimiliki perusahaan dan mengurangi dampak negatif dari ancaman yang ada. Kelemahan yang ada berupa promosi masih kurang meluas.

Ancaman yang ada berupa gencarnya promosi perusahaan lain sebagai rival PT. HTI Mandiri Palembang serta munculnya kompetitor baru dalam bidang properti dapat diminimalisir melalui strategi ini.

\section{Pembahasan}

Berdasarkan hasil analisis serta hasil observasi yang dilakukan oleh penulis maka dapat disimpulkan bahwa PT. HTI Mandiri Palembang sebagai perusahaan yang bergerak di bidang properti khususnya dalam penjualan perumahan sudah melakukan bauran pemasaran yang baik untuk mencapai target penjualan, dilihat dari produk yang dibuat selalu up to date mengikuti perkembangan jaman serta sangat memperhatikan kualitas rumah yang dibuat sehingga minat masyarakat terhadap rumah yang dibangun perusahaan cukup tinggi, kemudian dari sisi harga yang ditawarkan juga tidak terlalu tinggi sesuai dengan kualitas, desain rumah dan luas tanah yang di tentukan perusahaan yang di sesuaikan dengan lokasi pembangunan yang dipilih perusahaan sebagai tempat pembangunan rumah. Lokasi perumahan yang strategis berada di keramaian masyarakat dengan mengutamakan aspek keamanan serta kenyamanan para konsumennya juga sangat diperhatikan perusahaan guna menarik minat masyarakat terhadap rumah yang dibangun perusahaan karena lokasi merupakan salah satu faktor utama yang dilihat masyarakat sebelum membeli rumah, hanya saja ada bauran pemasaran yang masih kurang efektif pelaksanaannya yaitu bauran promosi karena lebih dominan hanya menggunakan pihak internal perusahaan dalam melaksanakan kegiatan promosinya tanpa menggunakan media masa ataupun media elektronik sehingga masih banyak masyarakat Palembang yang belum mengetahui perusahaan tersebut serta produk rumah yang dibuat. Dalam hal ini perusahaan seharusnya lebih memperhatikan lagi bauran promosi yang dilaksanakan sehingga akan lebih banyak masyarakat yang mengetahui produk rumah yang dibuat karena jika tidak memperluas jangkauan promosi maka akan membuat perusahaan pesaing yang lebih dikenal masyarakat kerena melakukan kegiatan promosi dengan maksimal sehingga keberadaan perusahaan pesaing lebih dikenal oleh masyarakat secara luas yang akan membuat masyarakat lebih banyak membeli rumah yang dibuat oleh perusahaan pesaing.

Selain menggunakan dan memperhatikan unsur-unsur penting bauran pemasaran, dalam penelitian ini juga dibantu dengan menggunakan bantuan Analisis SWOT yaitu evaluasi terhadap kekuatan, kelemahan, peluang dan ancaman yang diharapkan dapat lebih detail dalam mengupas dan 
membahas hal-hal penting dan apa saja yang harus dilakukan oleh PT. HTI Mandiri Palembang sehingga diharapkan dapat semakin membantu dalam menigkatkan kualitas bauran pemasaran yang lebih baik lagi untuk produk berikutnya dan tujuan perusahaan yang diharapkan akan lebih maksimal.

\section{J. Kesimpulan dan Saran \\ 1. Kesimpulan}

Berdasarkan uraian yang dikemukakan terdahulu, maka penulis mencoba untuk membuat kesimpulan dan saran yaitu :

a) PT. HTI Mandiri Palembang dapat dikatakan memiliki kualitas yang baik, terbukti dari kualitas dan desaign produk yang selalu modern dan jarangnya didapati keluhan dari para konsumen yang telah membeli produk PT. HTI Mandiri Palembang.

b) Harga yang ditawarkan tidak terlalu tinggi sesuai dengan kualitas, desain rumah dan luas tanah yang di tentukan perusahaan yang di sesuaikan dengan lokasi pembangunan yang dipilih perusahaan sebagai tempat pembangunan rumah

c) PT. HTI Mandiri Palembang umumnya melakukan penjualan langsung ke konsumen akhir sehingga dapat meminimalisasi harga jual akhir produk dan hal ini merupakan strategi harga yang baik untuk menghadapi para pesaing dalam industri yang serupa yang menggunakan perantara namun promosi yang dilakukan oleh PT. HTI Mandiri Palembang masih belum terlalu efektif karena hanya menggunakan pihak internal perusahaan dan tidak menggunakan media masa, elektronik ataupun media cetak.

\section{Saran}

Adapun hal-hal yang dapat disarankan dan dapat menjadi masukan bagi PT. HTI Mandiri Palembang yaitu :

a) Perusahaan harus selalu membuat produk rumah yang modern serta berkualitas baik untuk menarik minat dan memuaskan keinginan masyarakat akan produk rumah.

b) Lebih giat melakukan kegiatan promosi dengan cara menggunakan media elektronik, media massa ataupun media cetak sehingga banyak masyarakat yang tahu dengan produk yang dibuat oleh perusahaan dan akan berdampak pada semakin besarnya peluang perusahaan untuk mendapatkan konsumen baru.

c) Memperhatikan terobosan-terobosan baru perusahaan pesaing dalam menentukan produk, harga, dan melakukan promosi yang akan menjadi ancaman PT. HTI Mandiri Palembang di massa yang akan datang.

\section{DAFTAR PUSTAKA}

Gitosudarmo, $\quad$ Indriyo. 2008. Manajemen Pemasaran. Yogyakarta : BPFE.

Hermawan, Agus. 2012. Komunikasi Pemasaran. Jakarta : Erlangga.

Istijanto. 2009. Aplikasi Praktis Riset Pemasaran. Jakarta : PT Gramedia.

Kurniawan, Arief Rakhman. 2014. Total Marketing. Yogyakarta : Kobis.

Sumarni dan John Soeprihanto. 2010. Pengantar Bisnis. Yogyakarta : Liberty

Setiyaningrum, Ari, dkk. 2015. PrinsipPrinsip Pemasaran. Yogyakarta: Andi. 